\title{
The skaz, narrative mode in short stories by W. C. Scully, Percy FitzPatrick, Perceval Gibbon and Herman Charles Bosman
}

\begin{abstract}
While an overwhelning amoun of cultural activity worldwide has been (and is heing) conducled in sociedies which had (or have) very litlle or no knowledge at all of writing, and which can therefore be described as predominanly 'oral' cultures, very litlle attentpt has been made in the field of South African literature to examine how oral modes of cultural exchange influence and imerpenetrate the more recent written (literary) modes. Sonth Africa is a region which has several rich oral traditions and it is therefore importam to explore how aspects of these traditions are incorporated into (writlen) literature. This paper looks at the use of the fictional narrator and skaz (the Russian Formalist term meaning speech') in sone South African short stories by Scully, FizParrick, Gibhon and Bosman. It is argued that whercas Scully and FitzPatrick produce only partially successful narratives in the skaz style, Gibbon and Bosman introduce greater artistic and ideological complexity to the form.
\end{abstract}

\section{Introduction: The question of 'orality'}

This paper takes as its point of departure the notion that, in the diachronic view of human history, writing (and hence written literature) was preceded by many thousands of years of cultural life rooted in oral discourse. 'Oral discourse', or 'orality', may be taken here to mean the kind of social exchange uttered in spoken words, and refers to a mode of cultural interaction transacted by word of mouth in which one generation hands on to the next a body of lore, tales, proverbs and maxims without the intervention of the technology of writing. This kind of cultural interaction takes place pre-eminently in what Walter J. Ong (1982:1) refers to as "primary oral cultures", which he defines as "cultures with no knowledge at all of writing", but it may co-exist alongside new, literary forms 
of cultural expression. It may also - and this is the area of interest here -- exist as a trope within literary works.

Ong (1982:103) argues that the "psychodynamics of writing matured very slowly in narrative". By this he is alluding to the obstinacy of what he calls "oral residue", the elements of orality rooted so deeply in the human unconscious that they continue to influence patterns of thought and expression long after the advent of literacy. Literature itself lias been witness to the resilience of residual orality. Ong cites the dialogues of Socrates and his listeners as an example from classical times of an oral setting being rendered in written literature. Later, Boccaccio and Chaucer provided the reader with literature framed as storytelling events so that, says Ong, "the reader can pretend to be one of the listening company" (1982: 103). The point here is that, even in the highly literate, oral modes of thought and expression continued to exert an influence. Oral storytelling settings were frequently recreated in written literature, and Boccaccio and Chaucer are just two examples of this. 1

What, then, is the purpose of invoking an oral milieu in relation to the stories I have chosen to discuss? To return to the point above: modes of cultural interaction which have their origin in a social context in which oral discourse prevails, may come to exist as tropes within written discourse. One of the most important of these elements is that referred to by Ong in relation to Chaucer and Boccaccio: the re-creation, within a literary context, of an oral storytelling setting. The principal manner in which this is achieved is by the introduction of a storyteller figure (fictional narrator) who narrates the story. This device has of course become an established literary convention (two famous examples of this in modern literature are Mark Twain's seminal story "The Jumping Frog" and Joseph Conrad's Heart of Darkness). Its use in stories by the writers examined here probably testifies as much to the weight of literary influence as to the predominance of oral milieux in late nineteenth-century and early twentieth-century South Africa. (Bosman, for example, was possibly indebted for his Bushveld stories as much to the American yarnster tradition of Mark Twain and Bret Harte as to the immediate social context of the Marico.) Nonetheless, it is not fortuitous that all of the writers discussed here produced stories deeply redolent in style and substance of rural life in South Africa. The interest of this paper is in how elements which have their origin in an oral context function as literary devices.

A question which has frequently arisen in this context is whether it is appropriate to subject 'oral-derived' texts to the same techniques of analysis as those used to

I Here the reader's attention is drawn to Erncst Percira`s extremcly uscful essay (1986) on the fictional narrator in the South African short story 
interpret works of literature. It is not my purpose here to interrogate this old chestnut of orality-literacy studies. Since my paper is concemed explicitly with written literature (as opposed to oral art) the whole debate about the appropriateness of critical approach is simply not relevant. Works which may take the form of the written word but which are oral-derived in the sense that they were first performed and only later captured in writing are not my concern here. It is probably more accurate to speak of a spectrum or continuum of works ranging from oral performances to written works, with many works poised in between in varying degrees of indeterninacy, but it would be an error for me to assign anything but (written) literary status to works like those by Scully, FitzPatrick, Gibbon and Bosman that I examine here. Nonetheless, it is important to recognise that there are certain devices which have become assimilated into literature as literary conventions but which have their origin in an oral context. Chief among these (certainly as far as the short story is concerned) is the use of a fictional narrator and skaz narrative techniques.

\section{The skaz narrative form}

The introduction of a fictional narrator into the written story form constitutes an attempt to simulate the ethos of the spoken word on the written page. A useful way of discussing this deployment of oral discourse within written literature is provided by the Russian term skaz.

The Russian Formalist Boris Eichenbaum used the term skaz (Russian for 'speech') to describe literature which has "an orientation toward the oral form of narration" (quoted in Bakhtin, 1984:191). Anne Banfield (1982:171-72) has recently offered a useful interpretation of the Formalist use of the term. She argues that for the Russian Formalists, a tale in skaz was not accurately to be labelled 'oral', but was rather to be considered a written, literary imitation of a discourse. She herself defines $s k a z$ as "a kind of first person narrative which takes the form of discourse and is distinct from classic first person narratives like David Copperfield or A la Recherche du temps perdu" (Banfield, 1982:171). In conventional first-person narratives "a narrator narrates, but addresses the story to no one", whereas in skaz, according to Banfield, "the first person addresses a second and the story is told fornally as a communication" (ibid.:171). This has important implications for the structure of the narrative: the fictional narrator in skaz narratives, says Banfield, "addresses the tale to some audience, whose presence is linguistically reflected in the tale itself" (ibid:172); the "l-you" relationship, in other words, bestows its "communicative structure" on the narrative (ibid.:177). 
Mikhail Bakhtin took issue with Eichenbaum's definition of $s k a z$, claiming that he missed the most important dimension of the literary device. For Bakhtin, an important distinction in $s k a z$ is to be drawn between the type which displays "an orientation toward oral speech" (Eichenbaum's formulation) and, on the other hand, the type which displays "an orientation toward another person's discourse" (Bakhtin, 1984:192). The first case Bakhtin called "simple skaz", the second "parodistic $s k a z "$.

In simple skaz no attempt is made to stylize another person's individual manner of speech, the narrative is monologic in nature (in other words direct authorial discourse prevails), and the narrative therefore "directly expresses the intention of the author" (Bakhtin, 1984:191). Bakhtin uses Turgenev's story "Andrei Kolosov" as an example of simple skaz: the story is narrated by an intelligent and literary man of Turgenev's own circle, and the implication is that Turgenev would have told the story in the same way himself.

Parodistic skaz, on the other hand, introduces a storyteller figure precisely because of the individual attributes, attitudes and intonation that he brings to the story. These are distinct from the author's own voice and attitudes and a dialogic structure is therefore set up in which the author's intention is 'refracted' through the storyteller's act of narration. Bakhtin uses the example of Nikolai Leskov to illustrate this form of $s k a z$. Leskov, he argues, resorted to a narrator "largely for the sake of a socially foreign discourse and socially foreign worldview, and only secondarily for the sake of oral skaz" (Bakhtin, 1984:192).

The importance for Bakhtin of his refinement of Eichenbaum's original formulation is that he is able to distinguish between monologic (single-voiced) and dialogic (double-voiced) narrative forms. Dialogic narratives are inherently more complex and introduce the possibility of irony and parody, qualities that Bakhtin implicitly valorises.

\section{The skaz narrative and stories by Scully, FitzPatrick, Gibbon and Bosman}

How does all this apply to the South African stories I have selected to discuss here? I have selected just one story each by Scully and FitzPatrick (although other stories by these writers are briefly referred to), and use these stories as early instances of the fictional narrator in the South African short story. This sets the scene for a more extended analysis of story collections by Gibbon and Bosman: the implication is that in their hands the fictional narrator becomes a sustained structural device and that their more technically advanced use of the device is accompanied by a greater complexity of social and artistic vision. 
Each of the selected stories uses a skaz narrative style. Each attempts a literary imitation of spoken discourse by introducing a storyteller figure (a fictional narrator) from whose mouth the narrative ostensibly proceeds. There are significant differences, however, in the way the storyteller device is employed in each case. The presence of a frame narrator in the stories by Scully and FitzPatrick is strongly felt, and the relationship between him and his fictional narrator and/or interlocutors is fairly simple and transparent. This is not the case in the stories of Gibbon and Bosman. In Gibbon's stories the first-person narrator is introduced in a gradual fashion as the story-cycle unfolds. However, having established the setting - the Vrouw herself, her extended family and her social milieu - he withdraws and allows his storyteller to take centre-stage. In Bosman's case, the fictional narrator has become a first-person narrator. Someone, of course, 'relays' Oom Schalk's stories to the reader, but this is to be deduced only from the narrative structure of the stories. Oom Schalk's manner of telling implies a listener or, more probably, a group of listeners. The opening passage of "The LovePotion" is a good example of this: "You mention the juba-plant (Oom Schalk Lourens said). Oh, yes, everybody in the Marico knows about the juba-plant" (1988:56). This is an example of Banfield's "I-you" relationship set up by the narrative structure of the story. The 'you' mentioned by Oom Schalk is an implied interlocutor (not the reader) who exists on the same ontological plane as the fictional narrator.

When read in a sequence, the stories I have chosen to discuss - Scully's "Ukushwama", FitzPatrick's "The Outspan", the Vrouw Grobelaar tales of Perceval Gibbon and Bosman's Oom Schalk stories - reveal an increasing sophistication in the use of the skaz narrative mode. Whereas Scully and FitzPatrick employ a fairly simple relationship between teller and reporter of tale (between fictional narrator and frame narrator), Gibbon and Bosman introduce a great deal of irony into their 'Vrouw Grobelaar' and 'Oom Schalk' story-cycles. What began as a fairly adventitious deployment of elements of oral milieux for the sake of 'local colour' became a finely honed complex of literary devices which were capable of dealing on a formal level with the increasing complexity of life in South Africa. It is not perhaps fortuitous, therefore, that Gibbon and Bosman both produced whole sequences of stories. The success of the formula they adopted clearly encouraged them to produce successive stories with the same narrative structure.

Another tendency to be observed in this selection of stories is the growing complexity of narrative voice. The clear bifurcation of discourses (those of storyteller and frame-narrator/implied author) that we perceive in the story-cycles of Gibbon and Bosman would seem to imply that irony has become the appropriate vehicle for the portrait of a society increasingly riven by racial and class divides. Bakhtin's assertion in this regard is highly suggestive: 
Where there is no adequate form for the unmediated expression of an author's thoughts, he must resort to refracting them in someone else's discourse. Sometimes the artistic tasks themselves are such that they can be realised only by means of double-voiced discourse (Bakhtin, 1984:192).

The potential for irony and parody is more fully realised in the stories of Gibbon and Bosman when compared with those of Scully and FitzPatrick, and their stories are well-developed examples of, in Bakhtin's terms, "parodistic skaz". There are competing voices in both story-cycles and the relationship in each case between the fictional narrator and the frame narrator or implied author is mediated by layers of irony. This represents a more advanced use of the skaz narrative mode and indicates that Gibbon and Bosman both adopted a narrative form more suited to a critique of the communities they portray.

\section{Transkei legend: W. C. Scully's "Ukushwama"}

Selected stories by Scully have appeared in Jean Marquard's useful edition entitled Transkei Stories (1984). Several of the stories assembled by Marquard introduce elements of discourse germane to an oral milieu. It is evident in her selection, in fact, that Scully had an abiding interest in oral history and folklore. Most of the stories deal in some way or other with Nguni oral tradition: "The Quest of the Copper", from Kafir Stories (1895), is a fictional reconstruction of the adventures of an expedition commissioned by Shaka to find copper; "Gquma; or, The White Waif", from The White Hecatomb (1897), concerns the mythical origin of an exclamation uttered by the narrator's African companion, while the title story of this volume is the narrative (Marquard informs us) of "the daughter of a 'common man of the Amangwane tribe' caught up in the commotion of the Shaka era" (1984:xxi); "The Imishologu" (also from this volume) is an old man's account of a family tragedy and takes the form of an embedded narrative.

I propose to examine another story originally from Kafir Tales (reprinted in Transkei Stories) in some detail here, as it is an early instance of the use of a storyteller figure and is therefore of particular interest to the argument of this essay. The story, "Ukushwama", also has the distinction of being singled out and embellished by Bosman (I will return to this point later).

As is the case with many of the stories of this period, "Ukushwama" takes the form of an anecdote related in the first person. In the course of his business as the colonial administrator of a region of the Transkei, the narrator encounters a local myth about a pair of star-crossed lovers whose tragic demise haunts the region. The headman of the area, Numjala, warns the narrator that the forest he must pass in order to reach home is impassable on horseback on the night of the new moon. The narrator initially discounts the stony as an example of local superstition. Predictably, his dismissiveness is rewarded by a close encounter with 
the local shades: his horse indeed refuses to pass by the forest in which the lovers are buried and he is forced to return to the headman's kraal. This then provides the occasion for the embedded narrative in which some regional wisdom is imparted to the once sceptical administrator.

What we encounter in "Ukushwama" are two clearly demarcated narratives (labelled part I and II of the story) with clearly distinguishable narrators. The frame narrative uses the voice of a first-person narrator (the colonial administrator) to set the scene for the presentation of the framed story told by Numjala. In a concluding paragraph the voice of the frame narrator takes up the story once more. Although the two narratives are thematically linked (the collision of the sceptical white man with local lore triggers the explanatory story), they operate according to different conventions. The administrator's narrative is prefaced by a short poem (by Scully himself, under a nom-de-plume) and is characterised throughout by the tone of a white man in Africa, educated, literate, and eminently in command of the situation.

The embedded narrative is obviously relayed via the first-person narrator, and employs standard, grammatical English, but the author attempts to preserve some of the characteristics of the oral narrative: some Xhosa words are used (metia, lohola, ikazi, imfe - with the English equivalents in parentheses) and direct translations from the Xliosa are also present ("great son", "the feast of the first fruits", the "great place"). Numjala's narrative also bears some traces of the oral tale. The characterisation, for example, is schematic: Nomalie is the misprized princess, Xolilizwe her ill-fated lover whose social status is not commensurate with his attractiveness, and Lukwazi (who forces Nomalie to become his thirteenth wife), is the arrogant, drunken king, who misuses his power and spreads misery around him. He brings about the tragedy of the two lovers, but gets his just desserts soon afterwards.

A common characteristic of oral tales is their didactic intention. The use of human character-types rather than unique individuals is integral to this intention: the outcome of the story will often be evident to listeners merely on the presentation of characters at the outset. Numjala's narrative has a clear didactic message: interference with the natural course of love, arrogance (Lukwazi) and greed (Numjala himself, in 'selling' his daughter), bring unpleasant consequences.

Although there is an attempt to preserve the oral characteristics of Numjala's tale, it would be inaccurate to say that his narrative is untouched by the context of its retelling. Apart from the fairly obvious point that the language used sounds foreign on a Xhosa tongue, the 'oral tale' is clearly absorbed and redeployed within the contextualising frame of the written short story. In a very obvious sense, there are two voices present in the story. However, it would be incorrect to speak about 'parodistic' skuz here. For this element to exist, there must be an 
antagonistic or at least a competitive relationship between the two voices. The two narrators in "Ukushwama" may speak in stylistically distinct discourses, but the tale as a whole is unidirectional in tendency. Numjala 'speaks for' the administrator, and his story supplements the frame-narrator's own narrative. One voice is entirely domesticated by the other. In the narrator's framing story the moral dimension of the oral tale is subordinated to an overarching ideological tendency, that is, to convey the experiences of a colonial administrator in one of the far reaches of the Empire, to provide some local colour to a metropolitan audience. ${ }^{2}$

In faimess to Scully, it should be added that his attitude to Empire and British superiority was by no means a simple one. In her introduction to Transkei Stories Marquard provides ample evidence to show that Scully had very ambivalent feelings about British imperial rule, and showed considerable sympathy for the subjugated indigenous tribes and (later) also for the Boer cause. However, he was in other ways eminently a man of his time. In the conclusion to her introduction Marquard remarks:

The character of his fiction is marked by exotic, artificial and crudely simplified rhetorical patterns. The habit of locating 'laws' of nature in problems of an empirical nature exposes many of the underlying prejudices and limitations which are an integral part of the colonial imagination (Scully, 1984:xxiii).

\section{The frontier yarnster: FitzPatrick's "The Outspan"}

Sir Percy FitzPatrick's collection of stories, entitled The Outspan, first appeared in 1897, two years after the appearance of Scully's Kafir Stories. (A new edition of The Outspan was released by Lowry (1987), and I refer to this edition.) The title story is of particular interest here, as it employs a fictional narrator and evokes the fire-side ethos of the oral tale.

"The Outspan", as the title suggests, draws its subject-matter from a fire-side yarn-swapping session. The first-person narrator is unnamed, but is a clear presence from the opening passages of the story. He provides the frame in which the main story is embedded: several travellers are encamped one night under the stars and, as is customary in this kind of setting, the telling of stories soon commences. One of the characters at the fire-side, 'Barberton' (his place of domicile substitutes for his name), supplies the first half of the story, which concerns the

2 "Umtagati", another of Scully's storics from his first collection, demonstrates this intention morc conspicuously, and, as David Maughan Brown (1984:31-37) has argued, accomplishes it with barely concealed racism and condescension. 
unusual lifestyle of an acquaintance of his who goes by the name of 'Sebougwaan'. 'Sebougwaan' has two Swazi wives and adopts an African lifestyle. He eventually fetches up among the prospectors in Barberton, and dies a sudden, awful death from fever. Barberton recalls for his rapt audience's benefit the man's last, inexplicable cry: "Oh, my God! My poor wife!"

The enigma - who was his wife? why did he leave her? what kind of man was he? - is resolved unintentionally by another nember of the party: the 'surveyor'. (Here a profession substitutes for a name, the inference being that the company that night was composed of men who were interchangeable with others, who are 'types' rather than unique individuals.) The surveyor reports that he had a shipmate who was remarkable for his exemplary character, marred only by one flaw: his inability to forgive. This man suspected his wife of having affairs during his long absences at sea, settled his whole estate on her and their child and left England, never to return. The surveyor casually mentions his name at the end of his narrative and a shocked Barberton recognises his own 'Sebougwaan'.

In the framed story, then, there are two clearly identifiable narrators. Unwittingly, they provide two parts of the same story. Their two-part narrative is interrupted frequently by interlocuters: one anecdote merges with the next and the story as a whole displays a singular lack of economy. FitzPatrick is overwhelmed by his material. "The Outspan" is teeming with narratives, some of which interrupt others, while others are alluded to and serve inerely as digressions to the main story.

The relationship between the frame narrator and the participants in the fire-side yarn-swapping session is nonetheless a very simple one: he is a bystander who simply 'reports' the tales that unfold. There are six participating narrators in "The Outspan", and the story as a whole is a loosely-structured collection of anecdotes. Again, as with Scully, the voices heard do not compete in any ideological sense. The interest in the story is the overall lack of authorial management: there is no evidence, in fact, that any attempt at economy was made. The 'competition' between the voices, then, is more a consequence of bad stage-management than ideological conflict.

Indeed, FitzPatrick's story is a model of ideological complacency. There are two main thrusts to "The Outspan", neither of which points to any critical awareness on FitzPatrick's part. In the first place the frame narrator expresses a desire to evoke something of the lifestyle of the transport-riders, prospectors and others present in the interior at the time. He devotes much time to glorifying the style of life:

When a man has spent some years of his life ... in the veld, in the waggon, or tent, or bush, it is an almost invariable rule that something which you 
can't define germinates in him and never entirely dies until he does (FitzPatrick, 1987:2).

Clumsily inserted into this evocation of veld life is his attempt to address the familiar colonial bogey of civilisation's descent into barbarism upon its encounter with Africa. Sebougwaan 'goes native' and pays for it - "civilisation", as Barberton puts it, "scomed and flouted, [is] the instrument of its own revenge" (FitzPatrick, 1987:8). There is no discemible irony here: there is no evidence that the frame narrator would dispute Barberton's ideologically loaded claim. The various narrators may speak with different inflections, but they are all companions around the camp-fire and as such enjoy a kind of comradely equality. This also applies to the frame-narrator, whose task it is simply to relay the ethos of fire-side yam-swapping in nineteenth-century Africa. In the context of the period, the story's appeal would rest on its evocation of 'real-life adventure in Africa'. Its proclaimed closeness to lived experience bestows upon it an authenticity that would recommend it to the metropolitan reader thirsty for glimpses into the exotic outer reaches of the colonies. ${ }^{3}$

\section{A Boer storyteller: Perceval Gibbon's "the Vrouw Grobelaar"}

In comparison with Scully and FitzPatrick, Gibbon demonstrates a far greater skill with literary artifice and the art of storytelling, and this technical skill is accompanied by a more complex social vision. His use of a storyteller figure the redoubtable Vrouw Grobelaar - is not sporadic or opportunistic as it is in the case of the other two writers. (One suspects that in the case of both Scully and FitzPatrick the use of this device was suggested by the immediate context in which the tale was encountered.) The result is a well-crafted collection of compatible stories anticipating Bosman's Mafeking Road (1947).

The narrative structure of Gibbon's stories is highly effective. The presence of a narrating persona is scarcely perceptible at first, but is felt increasingly as the volume progresses until we learn that he is an English schoolmaster who is courting Katje and so encounters her aunt, the Vrouw Grobelaar. He reports the Vrouw's tales, but does so from the very margins of the narrative, allowing the Vrouw and Katje to be foregrounded.

3 "Induna Nairn", also included in FitzPatrick's collection, has a similar peripatetic quality to "The Outspan" - a long. scmi-cohercent narrative cloaked by a chauvinistic (in both senses) Victorian morality and all of the accompanying prejudices. Another ston;, "The Pool". again as David Maughan Brown (1984:28-30) has argued, mixes the racism of colonial idcology with the melodrama favoured by the age with similar results. 
The Vrouw's context is very much a rural one: the community is dependent on land and cattle for survival and is bound to the seasons. These God-fearing people are relentlessly engaged in a stark confrontation with the elements and a baneful fate which presides over the entire landscape. "The Boers", Gibbon remarks, "are a lonely folk and God's finger writes large in their lives." This, he says, is the reason for the Vrouw's "stores of tales" being "often horrible enough" (Gibbon, 1905:6).

As is typical in this kind of society, conversation on the stoep during the evening leisure hours ends in the telling of tales. The absence of any alternative entertainment and the curiosity stimulated by the flat continuity of their lives provide a fertile matrix for the oral tale. Casual and desultory conversation usually prompts the Vrouw to call forth a moral to encapsulate the topic of discussion which, in turn, is usually illustrated by a story.

Gibbon (1905:1-2) spends some time setting the scene. He describes his narrator as "a lady of excellent standing, as much by reason of family connections $[\ldots]$ as of her wealth":

Her face is a portentous mask of solemnity, and her figure is spacious beyond the average of Dutch ladies, so that certain chairs are tacitly conceded her as a monopoly. The good Vrouw does not read or write, and having never found a need in herself for these arts, is the least thing impatient of those who practise them. The Psalms, however, she appears to know by heart; also other portions of the Bible; and is capable of spitting Scripture at you on the smallest provocation.

What we have here, clearly, is a dexterously managed narrative structure in which the storyteller and the frame narrator occupy divergent ideological hemispheres. The frame narrator's dissenting voice is mute, but his condemnation of his storyteller's racism and hypocrisy is unmistakeable.

Throughout the book there is a disconcerting mixture of the comic and the tragic. In "The Peruvian" - which, the narrator informs us, is a blanket term for anyone for whose nationality the Vrouw has no name - the Vrouw warns against the dangers of dabbling with witchcraft. A young girl of the neighbourhood mysteriously disappears, and her family, having exhausted every other method, resolves to use the reputed divining powers of the itinerant Greek 'smouser' of the story's title. The girl's two burly brothers chance upon him after returning from another fruitless search. The 'capture' is described thus:

"The smouser, of course, whined and squirmed, but Piet was the man who broke the bullock's neck at Botha's kraal, and he made no difficulty of tying the little man's wrists to his off stirrup. All his trinkets and fallals they left behind, and riding at a walk, talking calmly between themselves of the buck 
with wide horns that the Predikant's cousin missed, they dragged the little smouser to the homestead" (162).

This casual brutality has a burlesque quality which makes it all the more shocking. The local witchdoctors, who are also coerced into aiding the search for the girl, "would have been glad enough to find her, for they were flogged from morning to night, and Barend van der Byl beat the life out of one who did not seem to be doing his best" (160). The gross injustices inflicted upon the subject native populace are reflected in this deliberately casual fashion. This conveys the sense of outrage on the frame-narrator's part that they should be there merely to suffer so arbitrarily the ire of any Boer in the vicinity.

Gibbon presents the Vrouw Grobelaar's racism and hypocrisy with irony. He exploits artfully the distance he establishes between his first-person narrator (who, it seems, approximates the author's own moral perspective) and his storyteller. He understands the Vrouw's prejudices intimately and positions her in such a way that her closed-mindedness becomes apparent and a source of amusement for the reader. Like Oom Schalk, the Vrouw Grobelaar is part comic and part sage. Deeply stamped by prejudice, she nevertheless has an ability to knit compelling narratives around a moral or an anecdote, and possesses a broader humanity which safeguards against the reader's alienation from her. Her very innocence of the irony of what she says is manipulated by the author for ironic effect.

The two voices that are heard in this story-cycle - that of the foregrounded raconteur and the silently manipulative first-person narrator - pull in different directions. The Vrouw articulates the dominant ideology of her society at the time, while the first-person narrator maintains a critical distance. This narrative structure enables Gibbon to develop an oblique but powerful indictment of the prejudices of the age.

\section{Bosman's Oom Schalk Lourens}

Gibbon's Vrouw Grobelaar has been eclipsed in the world of South African literature by Herman Charles Bosman's Oom Schalk Lourens. In 1930 Bosman's first major story, "Makapan's Caves", appeared under the pseudonym Herman Malan. The story introduced to the reading public South Africa's most famous fictional narrator, who memorably begins:

Kafirs? ... Yes, I know them. And they're all the same. I fear the Almighty, and I respect His works, but I could never understand why He made the kafir and the rinderpest (Bosman, 1969:61). 
From the very outset, then, Bosman was to make use of his very distinctive brand of irony, a device that has not always been properly interpreted by all readers of the Schalk Lourens stories.

Mafeking Road is rich in memorable stories, but one in particular demonstrates the peculiar brand of humour that Bosman made his own. In "In the Withaak's Shade" Oom Schalk describes his encounter with a leopard in the veld when he is out one day looking for strayed cattle. True to character, his search takes the form of lying under the shade of the 'withaak' tree. "I could go on lying there under the withaak and looking for the cattle like that all day, if necessary", he observes [my words - C.M], "As you know, I am not the sort of farmer to loaf about the house when there is a man's work to be done" (22)

To Oom Schalk's horror, a leopard appears, inspects him closely, and then goes to sleep next to him.

Of course, Oom Schalk's attempts to convince the local farmers of the truth of this the next day render him the laughing stock of the area:

I could see that they listened to me in the same way that they listened when Krisjan Lemmer talked. And everybody knew that Krisjan Lemmer was the biggest liar in the Bushveld (25).

In typical Bosman style, satire is subtly interwoven into Oom Schalk's narrative. Oom Schalk is partly vindicated when a leopard's spoor is discovered in the neighbourhood, and great excitement ensues. There is, we hear, "a great deal of shooting at the leopard and a great deal of running away from him". Says Oom Schalk:

The amount of Martini and Mauser fire 1 heard in the krantzes reminded me of nothing so much as the First Boer War. And the amount of running away reminded me of nothing so much as the Second Boer War (26).

This deadpan rendering is typical of Oom Schalk, who always knows more than he lets on, and whose subtle digs at the Bushveld Afrikaner are heavily cloaked in layers of irony.

Bosman's subject matter is not always so light-hearted. "The Music-Maker", for example, concerns a Bushvelder's attempt to transcend the stifling confines of backveld life by risking his musical talent in "the great cities of the world" (38). His venture takes him as far as Pretoria, where, in a reversal of the traditional 'rags to riches' story, he winds up playing on the pavements outside bars. Typically, the reader receives this information in the last sentence of the story, and the concealed ending contrasts strikingly with the light-hearted hilarity that pervades much of the narrative. 
It very soon becomes clear that Bosman's artistic concerns in Mafeking Road (and, of course, the other Bushveld stories that were collected posthumously) do not begin and end with a portrayal of South African backveld life. Critics have over the years argued convincingly that Bosman is insistently allegorising about wider issues that touch the entire South African population and, indeed, the world beyond.

As Martin Trump (1986) has observed, if one takes Bosman's stories as a purely realistic evocation of rural life, a number of serious misrepresentations of his work can ensue. Militant black critics, for example, could object to his flat portrayal of the blacks of the region, without perceiving how his work is in fact a severe indictment of racist practices in South Africa. And, from the other side of the political spectrum, reactionary whites could see in his work a light-hearted but realistic rendering of a lifestyle which vindicates the South African regime's dismissive attitude to the black population.

Against these misinterpretations Trump (1986:170) advances the view that Bosman uses the Marico framework as a literary device through which he creates a kind of "fabular account of the South African society". In Bosman's first Marico story "Makapan's Caves", for example, a Boer father offers his sons the following advice as they are going off on a punitive mission against a black tribe:

"Don't forget to read your Bible, my sons," he called out as we rode away. "Pray the Lord to help you, and when you shoot always aim for the stomach" (63-64).

The juxtaposition of religion and brutality in warfare is not accidental, Trump argues, and serves as a powerful indictment of the strategic Boer tendency to couple self-serving militarism with the belief in divine sanction.

The complexity of Bosman's artistic vision is accompanied by the deployment of technical devices which represent an advanced use of the $s k a z$ narrative mode. An important aspect of this is his artful foregrounding of narrative technique. The well-known opening to the title story of Mafeking Road is a good example of this:

When people ask me - as they often do, how it is that I can tell the best stories of anybody in the Transvaal (Oom Schalk Lourens said, modestly), then I explain to them that I just learn through observing the way that the world has with men and women (47).

He then punctures this spurious piece of philosophising by conceding that it is a lie: 
For it is not the story that counts. What matters is the way you tell it. The important thing is to know just at what moment you must knock out your pipe on your veldskoen, and at what stage of the story you must start talking about the School Committee at Drogevlei. Another necessary thing is to know what part of the story to leave out (47).

This kind of direct intra-textual reference to the mechanics of fictionalising is indicative of a self-consciousness in the way Bosman crafts his stories - a selfconsciousness absent in the early skaz narratives of Scully and FitzPatrick.

\title{
8. Bosman and metafictional experimentation
}

In some of Bosman's later stories (eg. Unto Dust), this foregrounding of literary device approaches the level of metafictional experimentation. An example of this is his redeployment of Scully'z "Ukushwama", in which he uses this ghost story as a preface to his own "Old Transvaal Story", which originally appeared in 1948.

\begin{abstract}
As Scully, I think, knew - have you ever chanced upon his "Ukushwama"? - the Transvaal seems to have had only one ghost story. It is a story that I have heard very often, told over and over again in voorkamer and by campfire, with the essential features always the same, and with only the details, in respect of characters and locale, differing with the mood and the personality - and the memory, perhaps - of each person that tells it (1963:107).
\end{abstract}

What Bosman then proceeds to do is artfully merge a discussion of the Transvaal's 'only ghost story', and its 'only murder story'. with a variation of his own on these 'many-told' tales. The passage of the fitty-odd years between Scully's story and Bosman's re-telling has some interesting effects on the narrative texture of the tale. Where Scully"s story is told as a fairly ingenuous piece of local colour, in Bosman's rendering the artifice of the tale is foregrounded. Bosman sends up the genre of the 'ghost story': his conversational, light-hearted tone runs directly counter to the atmosphere that traditionally envelops a rendering of the tale, and where the storyteller would normally attempt to conjure up suspense in the opening part of his tale, Bosman addresses the reader directly. He eschews the customary device of his raconteur Onm Schalk, and lures the reader into believing that a discursive rather than narrative piece will unfold. Of course, towards the end of the piece Bosman changes gears and the story ends climactically. After a long, playful introduction to the infinite fictional possibilities inherent in relating the Transvaal's only ghost story and its only murder story, Bosman concludes tersely with his own version of the story of Gideon Welman, the man who murdered his wife and buried her under the dung floor of the voorkamer

And then events slid into that afternoon on which Gideon Welman was working very fast, and in a half-daze. He had the queer feeling that he was 
living another life, going through a thing that had happened before, to somebody else, long ago. It was quite dark by the time a knock came at the door. And when he got up from the floor quickly, dusting his knees, Gideon Welman knew what that old Transvaal story was, into whose pattern his own story had now fitted, also (1963:112).

Of interest here are the proto-metafictional aspects in Bosman's rendering of the tale. The merging of genres (discursive, fictional) is only one example of this. Bosman is also supremely conscious of the impossibility of being entirely original in the telling of a story: a story one tells is inevitably a reconstitution of the 'always already written', to use Roland Barthes's famous phrase, and Bosman implicitly acknowledges this here. What remains to the writer, therefore, is the self-conscious redeployment of pre-existing materials, a process Bosman puts into practice with consummate mastery in this story.

\section{Beyond Oom Schalk}

The $s k a z$ tradition in the South African short story reaches a high point in the Oom Schalk stories, but it is a style which continues to appear (albeit somewhat sporadically) in the contemporary South African short story. Some of the stories in Barney Simon's .Jo burg, Sis! (1974), for example, attempt to evoke the texture of city slang by using a $s k a z$ style. And oral influence on the black short story or, more accurately, the reappropriation of an oral tradition by black slort-story writers - in fact only emerges later, a process heralded by the appearance of A.C. Jordan's Tales from Southern Africa in 1973. Bessie Head's The Collector of Treasures (1977), which is subtitled "and Other Botswana Village Tales", has an intimate and productive relationship to the traditional narrative discourse of the rural Botswana village; and Mtutuzelı Matshoba (1979), Mbulelo Mzamane (1980) and Njabulo Ndebele (1983) all draw heavily on the contemporary 'orature' of the black township and elements of African oral tradition in the fashioning of their stories. However, while the skaz narrative clearly survives the last Oom Schalk story, the style of the post-1948 short story (dominated by Paton, Gordimer, La Guma, Matthews, Rive and others) is overwhelmingly social realist in nature, and the setting is invariably an uban one. ${ }^{4}$

4 The city setting that is characteristic of the post-1948 South African short story caused Njabulo Ndcbele to complain that this setting is invariably accompanicd by an overpoliticised content The city he asserts. "appears to have held tyrannical hold on the imagination of the average $A$ frican worker" (1984.43) Springing from this, he argues. Is a body of writing which concurns itself almost sol:ly with overtly political themes. Ndebele's point is that black South African literature has been mpoverished by city-based proteststyle work, and he urges a return to rural origins and indigenous oral cultures 
The intriguing feature of this shift of literary focus, triggered by the steady movement of people from the outlying areas to the towns and cities, is that it finds a resonance in Bosman's own oeuvre. In her review of the posthumously published Jurie Steyn's Post Office and A Bekkersdal Marathon (both 1971) Gillian Siebert (1986:74) notes the distance between these two works and the earlier collections of stories, and argues that "in the gap between the world of Oom Schalk and Jurie Steyn's post office Bosman shows, as no other South African writer has done, the passage of twenty-five years on his people and his country". In Bosman's own lifetime, in other words, the fictional locale of the Marico was in the process of disappearing. The legendary long grass of the Marico was giving way to patches of thorny scrub and the young men and women of the district, daunted by the task of wresting a living from the semi-desert soil, had long since begun their trek to the cities. As early as 1965 David Goldblatt had recorded this demise. Stephen Gray (1977:85) has also noted that

... the Voorkamer Marico exists almost a generation later, and it features farmers deracinated from the past, and detached from the present which they are ill-equipped to handle. And they are now imprisoned, impotently, within the four walls of the Drogevlei Post Office, cut off from the veld outside

This change is reflected in interesting ways in the stories themselves: the stable fictional narrator is replaced by the 'conversation forum' that is Jurie Steyn's voorkamer. A satisfactory resolution to issues raised is seldom achieved, and the unified and essentially optimistic vision of Oom Schalk is replaced by the desultory to-and-fro of discussion between the disgruntled characters in the voorkamer.

\section{Conclusion}

In the stories of Gibbon and Bosman the South African skaz narrative achieves a tight and well-developed form. Whereas the earlier efforts of Scully and FitzPatrick to invoke an oral storytelling context on the written page yielded narratives which were loose and peripatetic as well as ideologically uncritical in nature, the story-cycles of Gibbon and Bosman are crafted, economical and ideologically sophisticated. Both Gibbon and Bosman refract their narratives through fictional narrators, and this greatly enhances the potential for tacit ironic com- 
mentary. 5 Gibbon's pioneering efforts in this regard (he wrote his stories some 25 years before the first Oom Schalk tale) are remarkable and unjustifiably neglected.

\section{References}

Bakhtin, Mikhail. 1984. Problems in Dostoevsky's Poetics. Ed. and transl Caryl Emerson. Minneapolis : University of Minnesota Press.

Banfield, Anne. 1982. Unspeakable Sentences: Narration and Representation in the Language of Fiction. London : Routledge \& Kegan Paul.

Bosman, Herman Charles. (1947) 1969. Mafeking Road. Cape Town : Human and Rousseau.

Bosman, Herman Charles. 1963. Unto Dust. Cape Town : Human and Rousseau.

Bosman, Herman Charles. 1971. A Bekkersdal Marathon. Cape Town : Human and Rousseau.

Bosman, Herman Charles. 1971. Jurie Steyn's Post Office. Cape Town : Human and Rousseau.

FitzPatrick, J. Percy. (1897) 1987. The Outspan. Johannesburg : Lowry.

Gibbon, Perceval. 1904. Souls in Bondage. Edinburgh \& London : Blackwood.

Gibbon, Perceval. 1905. The Vrouw Grobelaar's Leading Cases. London : Blackwood.

Gibbon, Perceval. 1911. Margaret Harding. London : Methuen.

Goldblatt, David. (1965) 1986. Bosman's Bosveld Revisited. In: Gray, Stephen (ed.) Herman Charles Bosman. Johannesburg : McGraw-Hill. p. 53-54.

Gray, Stephen. 1977. Bosman's Marico Allegory: A Study in Topicality. English Studies in Africa, 20(2):79-94.

Head, Bessie. 1977. The Collector of Treasures and Other Botswana Village Tales. London : Heinemann.

Jordan, A.C. 1973. Tales from Southern Africa. Berkeley \& Los Angeles : University of California Press.

Matshoba, Mtutuzeli. 1979. Call Me Not a Man. Johannesburg : Ravan.

Maughan Brown, David. 1984. On the Reading of Readings of Texts. Social Dynamics, 10(1):26-37.

Mzamane, Mbulelo. 1980. Mzala. Johannesburg : Ravan.

Ndebele, Njabulo S. 1983. Fools and Other Stories. Johannesburg : Ravan.

Ndebele, Njabulo S. 1984. Turkish Tales, and Some Thoughts on South African Fiction. Staffrider, 6(1):24-25, 42-48.

Ong, Walter J. 1982. Orality and Literacy: The Technologizing of the Word. London : Methuen.

5 It is fascinating in this regard to observe how unsuccessful Bosman's novels were in relation to his Bushveld stories. They are much more direct in their attempt to deal with the racial problems in South African society and even on the most sympathetic of readings can only be described as partially successful. This is also partly true of Gibbon: Souls in Bondage (1904), the novel he wrote around the same time that he was composing the Vrouw Grobelaar tales, is a singularly unsuccessful attempt to deal with race relations in South Africa - an issue far better handled in "Unto the Second Generation" and other stories from The Vrouw Grobelaar's Leading Cases. Howcver, Gibbon's Margarel Haring (1911) is a far more successful novel, and is justifiably the work for which he is best known. 
Pereira, Ernest. 1986. Tall Tellers of Tales: Some Fictional Narrators and their Function in the South African Short Story in English. In: Gray, Stephen (ed.) Herman Charles Bosman. Johannesburg: McGraw-Hill. p. 103-115.

Scully, W. C. (1895) 1984. Transkei Stories. Cape Town : Philip

Siebert, Gillian. (1972) 1986. 'A More Sophisticated Bosman': Review of Jurie Steyn's Post Office and A Bekkersdal Marathon. In: Gray, Stephen (ed.) Herman Charles Bosman. Johannesburg : McGraw-Hill. p. 72-74.

Simon, Barney. 1974. Joburg, Sis! Johannesburg : Bataleur.

Trump, Martin. 1986. The Short Fiction of Herman Charles Bosman. In: Gray, Stephen (ed.) Herman Charles Bosman. Johannesburg : McGraw-Hill. p. 164-178.

\section{Rand Afrikaans University}


